\title{
Nařizení Evropského parlamentu a Rady č. 230/2014
}

\author{
Michael Urban \\ Západočeská univerzita v Plzni, Fakulta právnická
}

Anotace: Tento článek se zabývá nařizením Evropského parlamentu a Rady (EU) č. 230/2014, který do unijniho práva zavádí „nástroj přispivající ke stabilitě a míru. Článek analyzuje jak teoretická východiska tohoto nástroje, tak praktické dopady aplikace tohoto nařizení zejména analýzou praktických projektů, které jsou díky tomuto nařizení realizovány. Dále je v článku rozebírána povaha jednotlivých nástrojů tohoto nařízení. Stručně je taktéž zmíněna ekonomická stránka a rozpočtové dopady.

Klíčová slova: vnějši politika EU, nástroj přispivající ke stabilitě a míru

\begin{abstract}
This article will introduce you to the Regulation (EU) No 230/2014 of the European Parliament and of the Council, which deals with the Union law "an instrument contributing to stability and peace." This article breaks down both the theoretical basis of this tool and the practical implications of the application of this regulation, especially by analyzing practical projects that are implemented thanks to this regulation. Furthermore, the article discusses the nature of the individual instruments. The economic side and
\end{abstract}


budgetary implications are also briefly mentioned.

Keywords: European Union law, external policy of the European Union, instrument contributing to stability and peace

\section{Úvod}

Nařízením Evropského parlamentu a Rady (EU) č. 230/2014 ze dne 11. března 2014 byl do unijního práva zaveden „nástroj přispívající ke stabilitě a míru“. Jedná se o hlavní nástroj Evropské komise, kterým přispívá ke zlepšení bezpečnostní situace $v$ partnerských zemích. Jedná se o subsidiární nástroj, který se použivá $v$ prípadech, kdy zlepšení bezpečnostní situace $v$ partnerské zemi nelze dosáhnout běžnými způsoby.

Ambicí tohoto nástroje je tedy řešit takové faktory, jakými jsou terorismus, organizovaná trestná činnost, násilí na základě pohlaví, změna klimatu, problémy v oblasti kybernetické bezpečnosti a bezpečnostní hrozby související s prírodními katastrofami, a to výhradně směrem vně Evropské unie, tedy vůči třetím státům, a nikoliv členům samotné Evropské unie.

Tento nástroj není zdaleka tím jediným, který Evropská unie využívá v souvislosti se svoji vnějši politikou. Mám ale za to, že se jedná o nástroj, bez kterého by veškerá dalši činnost Evropské unie neměla jakýkoliv smysl.

Ideová východiska podobného institutu nalezneme již mnohem dřive. Samotné nařizení se odkazuje na svého předchůdce, který byl stejně jako v tomto případě přijat na dobu určitou a jeho platnost a účinnost končila k 31. 12. 2013. 
Toto nařizení na něj bezprostředně časově navazuje a jeho účinnost je taktéž časově omezena do 31. 12. 2020. Přesto, že by se mohlo na první pohled zdát, že stanovit takovouto normu, která má bezesporu poměrně velký dopad pouze na určitý časový úsek, by mohlo být nelogické, je pro to jeden poměrně velmi logický argument. Účinnost tohoto nařizení je shodná s víceletým finančním rámcem, se kterým je svázána, protože finanční prostředky jsou uvolňovány právě na základě ročniho rozpočtu v rámci víceletého finančniho rámce.

\section{Obecná charakteristika}

Oproti svému předchůdci můžeme již na první pohled vypozorovat několik změn. Oproti předchozí úpravě je nově slovo "mír" obsaženo prímo v názvu tohoto nástroje, došlo k navýšení prostředků o $11 \%$ a nově taktéž došlo $k$ tomu, že toto nařizení bude reagovat na terorismus.

Toto nařizení je tedy jedním z nástrojů, které logicky přímo přispivají $k$ vnější politice Evropské unie ve smyslu čl. 21 SEU. Celková částka, která má být rozdělena $v$ rámci jednotlivých projektů, je poměrně velmi vysoká. Konkrétně se jedná o $2338719000 €$. Celkem bylo již k tomuto dni v rámci tohoto nařizení řešeno 404 programů (nejspíše nemusely být schváleny). Pouze pro ilustraci, na deset finančně nejnáročnějších projektů pouze za rok 2018 bylo vyčleněno více než 65 miliónů eur. $^{2}$

${ }^{1}$ Tento článek se zabývá vnější činností EU, z čehož vyplývá, že cílem tohoto nástroje budou nečlenské státy.

${ }^{2}$ INIIGUEZ DE HEREDIA, Marta. Instrument contributing to Stability and Peace - 10 most 
Na první pohled se může zdát, že částka, kterou Evropská unie vyčlenila na tento program, je poměrně velká, ovšem porovnáme-li to s jinými obdobnými programy, zjistíme, že je to vlastně docela "chudý príbuzný“. Například na Evropský sousedský program je vyčleněno $19 \mathrm{mld}$. €. ${ }^{3}$ Tato částka ovšem mohla být ještě mnohem nižší, a to o 100 miliónů eur. Členské státy totiž v roce 2017 rozhodly, že bude o tuto částku zvětšen rozpočet. Tyto prostředky byly přidány do celkového rozpočtu za tím účelem, aby mohly být $\mathrm{v}$ rámci tohoto nařizení řešeny i záležitosti, které byly řešeny prostřednictvím iniciativy s názvem Capacity Building in Support of Security and Development (CBSD). Tato iniciativa tedy byla v roce 2017 po poměrně vleklé a kontroverzní diskuzi implementována. ${ }^{4}$

Tato implementovaná iniciativa se taktéž v podstatě zabývala přispíváním ke stabilitě a míru, ovšem mírně rozdílnými prostředky, než je tomu u nástroje. Tato iniciativa se zaměřovala především na výcviky pravidelných vojenských jednotek a podobně, což byl také jeden z hlavních argumentů, které zaznívaly od kritiků této implementace. Těm vadilo zejména to, že začne postupně docházet $k$ sekuritizaci rozvojové politiky Evropské unie. ${ }^{5}$

funded projects in 2018 [online]. [cit. 2019-07-30]. Dostupné z: https://zenodo.org/ record/3243973\#.XUCNV44zaW8

${ }^{3}$ BERGMANN, Julian. A Bridge over Troubled Water? The Instrument Contributing to Stability and Peace (ICSP) and the Security-Development Nexus in EU External Policy [online]. Bonn: Deutsches Institut für Entwicklungspolitik, 2018, s. 11 [cit. 2019-0523]. ISBN 978-3-96021-062-7. Dostupné z: https://www.die-gdi.de/uploads/media/ DP_6.2018.pdf

${ }^{4}$ BERGMANN, Julian. Capacity Building in Support of Security and Development (CBSD): Securitising EU Development Policy? [online]. Bonn: Deutsches Institut für Entwicklungspolitik, 2017, s. 11 [cit. 2019-07-28]. ISBN 978-3-96021-062-7. Dostupné z: https://www.die-gdi.de/uploads/media/BP_24.2017.pdf ${ }^{5}$ BERGMAN, tamtéž. 
Hlavní důvod pro to, že byla tato iniciativa implementována, je poměrně jednoduchý. $V$ první řadě stát zcela samozřejmě potřebuje funkčni státní instituce, jakými jsou například vláda či těleso vykonávající funkci parlamentu. Ovšem jakkoliv sofistikovaná státní struktura nebude schopna delšího fungování, pokud nebude mít jinou složku, jejímž hlavním úkolem bude takovéto těleso chránit a $v$ krajních prípadech prosazovat jeho vůli. Takovýmto tělesem bývá zpravidla armáda. ${ }^{6}$

\section{Věcná působnost nařízení}

Veškerou věcnou působnost tohoto nařízení Ize rozdělit do tři „makrosektorů“. Prvním makrosektorem je bezpečnost, stabilita a mír, druhým budování míru, budování státu a vlády, třetím pak úleva od prožitých strastí, rehabilitace a vývoj. Těmito třemi „piliři“ pak ještě prostupují jakési univerzální principy, na které má být pamatováno za jakékoliv situace. Těmito principy jsou: gender, lidská práva, citlivost na konflikty a synergie s ostatními programy uskutečňujícími se v rámci tohoto nařizení. ${ }^{7}$

\footnotetext{
${ }^{6}$ BERGMAN, Julian. Capacity Building in Support of Security and Development (CBSD): Securitising EU Development Policy? [online]. Bonn: Deutsches Institut für Entwicklungspolitik, 2017 [cit. 2019-07-30]. Dostupné z: https://www.die-gdi.de/en/ briefing-paper/article/capacity-building-in-support-of-security-and-development-cbsd -securitising-eu-development-policy/

${ }^{7}$ Evropská komise. Instrument contributing to Stability and Peace manual_of_indicators [online]. Brusel, 2016, s. 16 [cit. 2019-07-28]. Dostupné z: https://www.transtec. be/website2/pixportal.nsf/pGen00/TRAC-AHVLD6/\$FILE/manual_of_indicators.pdf
} 
Cíle tohoto nařizení mají být specifické:

- $\quad v$ krizových situacích nebo $v$ případě vznikajících krizí urychleně přispivat $k$ nastolení stability účinnou reakcí, která má pomoci zachovat, vytvořit nebo obnovit podmínky potřebné $\mathrm{k}$ raádnému prováděni vnějších politik a činnosti Unie podle článku 21 Smlouvy o EU;

- přispívat $k$ předcházení konfliktům a zajištování kapacity a prípravenosti $k$ řešení situací před krizí a po ní a budování míru a

- řešit specifické globální a nadregionální hrozby ohrožujicí mír, mezinárodní bezpečnost a stabilitu.

Přesto, že výčet bude $v$ tomto případě taxativní, bude fakticky aplikovatelný na poměrně širokou a téměř neomezenou škálu záležitostí. Konkrétní druhy pomocí jsou:

- pomoc $v$ reakci na krizovou situaci nebo vznikající krizi s cílem předejít konfliktům (čl. 3);

- pomoc určená pro předcházení konfliktům, budování míru a připravenost na krize (čl. 4);

- pomoc při řešení globálních a nadregionálních hrozeb a vznikajících hrozeb (čl. 5).

Pod každou touto pomocí je stanoveno poměrně velké množství jednotlivých „skutkových podstat“, které jsou zde řešeny a na které může být poskytnuta pomoc.

Přesto, že doba, kdy je nařízení, které zavádí nástroj přispívající ke stabilitě a míru, v účinnosti pouze do roku 2020, vše nasvědčuje tomu, že rok 2020 nebude posledním rokem, 
kdy se s takovýmto či podobným institutem v právním ráadu Evropské unie setkáváme.

Jako příklad může posloužit článek 5 tohoto nařízení, který v současné době mírí na globální a nadregionální hrozby. Věcná působnost tohoto článku má být zjevně v dalším funkčním obdobní ještě rozšířena, a to konkrétně o hrozby, které se budou vyskytovat v souvislosti se změnou klimatu, a má se více zaměřovat na kybernetickou bezpečnost. Poměrně rozumným rozšířením tohoto článku je pak zvýšení rozpočtu na terorismus, a to rovnou o $400 \%{ }^{8}$

\section{Rámec podpořených projektů}

V rámci současného znění tohoto nařizení byly podpořeny projekty na všech kontinentech mimo Austrálie. Zcela logicky nejvíce peněžních prostředků směřuje do Afriky. Konkrétně do Subsaharské Afriky přiteklo $31 \%$ z celkového objemu finančních prostředků. ${ }^{9}$ Pro představu pouze do Libye přiteklo $29000000 €$.

Vzhledem $\mathrm{k}$ tomu, že věcná působnost tohoto nařizení je opravdu široká, bude také široké spektrum projektů, které budou $v$ rámci tohoto nařizení podporovány. Vedle sebe se

\footnotetext{
${ }^{8}$ MIRANDA, Valérie. Justice cooperation in criminal matters under the EU Instrument contributing to Stability and Peace [online]. Řim, 2014 [cit. 2019-07-30]. Dostupné z: https://www.giustizia.it/resources/cms/documents/italia2014_ue_roma_miranda.ppt ${ }^{9}$ BERGMANN, Julian. A Bridge over Troubled Water? The Instrument Contributing to Stability and Peace (ICSP) and the Security-Development Nexus in EU External Policy [online]. Bonn: Deutsches Institut für Entwicklungspolitik, 2018, s. 12 [cit. 2019-05-23]. ISBN 978-3-96021-062-7. Dostupné z: https://www.die-gdi.de/uploads/media/DP -6.2018.pdf
} 
tedy potkává opravdu široká paleta různě zaměřených projektů, at už je to projekt z roku $2017^{10} \mathrm{~s}$ poměrně vtipným názvem „Make Colombia Great Again“, který je zaměřen na asanaci zaminovaných území (na tento projekt šlo konkrétně $1800000 €$ ) a který dle mého názoru může ve svém faktickém důsledku přispět mnohem efektivněji (i když se nejedná čistě o mír a stabilitu stricto sensu) než projekt, který má název Negociace budoucnosti evropských zdrojů pro podporu mediace, na který bylo vyčleněno $5682400 €$.

Osobně mám za to, že takovýto megalomanský projekt je i přes možné částečné úspěchy odsouzen $\mathrm{k}$ záhubě jako celek. Podiváme-li se na tento projekt bliže, zjistíme, že se pod tímto na první pohled vznosným názvem schovává poměrně nesourodá skupinu projektů. Napřiklad v oblasti Středního východu a severní Afriky se jedná o zvýšení vlivu žen na bezpečnostních a rozvojových výzvách. Myslím si, že zrovna tato problematika není úplně tím, co by trápilo státy, jako je Libye a podobně.

Ovšem zdaleka se nejedná pouze o takové státy, které většina Evropy označuje jako státy rozvojové či státy tzv. „třetího světa“. Jedním z mnoha projektů podpořených $v$ rámci tohoto nástroje je napríklad projekt realizovaný neziskovou organizací International Alert. Tento projekt má podpořit odolnost ukrajinské společnosti vůči dopadům konfliktu a sociálního napětí a posílit schopnost společnosti zmírnit rizika dalších připadných budoucích konfliktů. Tohoto cíle má být dosaženo tím, že bude postupně vybudována kapacita, která bude spočivat $v$ tom, že budou vytvořeny neformální sítě různých

${ }^{10}$ Nástup Donalda Trumpa do úradu je k 20. 1. 2017. 
organizací - nejspíše neziskových, které budou lokalizovány $v$ různých oblastech země za účelem vytváření analýz místních konfliktů. Tyto organizace pak budou spolupracovat s místními vládními strukturami na „identifikaci problémů a rozvoji priorit a řešení budování míru". "11

\section{Rozdělení finančních prostředků}

Co se týče samotného procentniho rozdělení finančních prostředků, dle samotného textu nařízení musí 70 \% být vyčleněno na pomoc předcházení konfliktům ve smyslu čl. 3 a $9 \%$ na pomoc určenou pro předcházení konfliktům, budování míru a připravenost na krize ve smyslu čl. 4. Zbylých $21 \%$ není výslovně upraveno.

Dospět lze tedy dle mého soudu ke dvěma názorům. Budto je počitáno s tím, že každý průměrně rozumný člověk je schopen si dopočitat, kolik procent má jít na pomoc při řešení globálních a nadregionálních hrozeb a vznikajících hrozeb nebo tento jediný bod předpokládá, že prostředky vložené do tohoto mohou a nemusi být vyčerpány vůbec nebo v nižší procentní výši.

Je taktéž zajímavé sledovat, jaké procentní podíly jsou priirazovány jednotlivým tématům. To považuji za jeden z největších problémů v prípadě tohoto nařizení. Na budování důvěry, zprostředkování a dialog prípadá z celkového objemu $19 \%$, což je přibližně 444 miliónů $€$. Na druhé straně protiteroristické

${ }^{11}$ Podrobný popis programu dostupný zde: https://www.international-alert.org/ru/ projects/reweaving-ukrainian-social-fabric 
a antiextremistické projekty "ukously“ z celkového koláče pouze $4 \%$ což představuje částku 93 miliónů $€$, což se mi jeví jako zcela neopodstatněné zejména s ohledem na to, do jakých států má být tato pomoc distribuována. Efektivnější by tato pomoc byla, pokud by se procentuální poměry u těchto čísel vzájemně prohodily.

Bez povšimnutí nemůže zůstat ani institucionální rámec tohoto nařizení, a to jak z pohledu Evropské unie, tak z pohledu organizací, které poskytnutou finanční pomoc fakticky distribuuji v cílových destinacích. Penize na tyto programy přicházejí z různých „zákouti““ evropského rozpočtu. Neexistuje tedy jedno centralizované místo, kam by byly finanční prostředky soustředěny a odkud by se předávaly dále. Zatímco problematiky dle čl. 3 a 4 jsou obsaženy v linii rozpočtu č. 1902, kde jsou unijní prostředky na zahraniční politiku, tak problematika čl. 5 je obsažena v linii 2105 obsahující prostředky pro mezinárodní rozvoj a spolupráci. Překážkou by možná ani tak nebylo samotné oddělení těchto prostředků do několika rozpočtových složek, ale to, že s každou složkou logicky nakládá jiné těleso. První dvě jsou spravovány Službou pro nástroje zahraniční politiky a poslední složka Generálním ředitelstvím Komise pro mezinárodní spolupráci a rozvoj (DEVCO).12 Může se tedy stát, a nejspiše se i stává, že v některých připadech levá ruka neví, co dělá pravá, a naopak.

Samotná faktická pomoc neprobíhá prostřednictvím orgánů Evropské unie, ale za pomoci subjektů, které jsou od EU zcela odlišné. Největší procento projektů z těchto prostředků

${ }^{12}$ Tamtéž, str. 12. 
realizuje Organizace spojených národů, a to celých $32 \%$, $30 \%$ potom mezinárodní a lokální nevládní a neziskové organizace.

\section{Právní povaha jednotlivých nástrojů a finanční rámec}

Jednotlivé nástroje ve smyslu čl. 3-5 maji taktéž rozdílnou povahu, zatímco aktivity podle článku 3, tedy aktivity, které mají reagovat na krizovou situaci, maji být prováděny jako opatření mimořádné povahy, tzv. EAM. To může trvat až 18 měsíců a případně může být prodlouženo o dalších 12 měsíců. Celková doba opatření nesmí v žádném připadně přesáhnout 36 měsíců. Pokud je nástroj přijímán jako EAM, pak zcela logicky nebude potřeba, aby byl projednáván ve výborech. Jsou zde ale samozřejmě výjimky. Jeden výbor se do projednávání zapoji pokaždé. Konkrétně se jedná o výbor pro politiku a bezpečnost. Druhou výjimku představují opatření, na která by bylo vynaloženo více než 20 miliónů $€$. $V$ takovémto případě už bude muset všemi možnými výbory projít.

Stejný nástroj ale může být přijat i jako program dočasné reakce. Ten ale již bude vyžadovat složitější postup pro svoji účinnost, protože vyžaduje rozhodnutí ve výborech, přesto, že je fakticky taktéž založeno na EAM. ${ }^{13}$ Obecně Ize ríci, že nástroje podle článku 3 jsou přijímány za účelem

${ }^{13}$ BERGMANN, Julian. A Bridge over Troubled Water? The Instrument Contributing to Stability and Peace (ICSP) and the Security-Development Nexus in EU External Policy [online]. Bonn: Deutsches Institut für Entwicklungspolitik, 2018, s. 12 [cit. 2019-05-23]. ISBN 978-3-96021-062-7. Dostupné z: https://www.die-gdi.de/uploads/media/DP -_6.2018.pdf 
co nejrychlejší reakce, zbylá opatření podle čl. 4 a 5 , tedy pomoc určená pro předcházení konfliktům, budování míru a připravenost na krize (čl. 4) a pomoc při řešení globálních a nadregionálních hrozeb a vznikajících hrozeb (čl. 5), již ze své podstaty jsou prijímána jako dlouhodobé instituty.

Tyto dva instituty jsou prijímány na základech tematických strategických dokumentů a víceletých orientačních programů. A jeden je vždy podmíněný druhým. Samotné nařizení za základní nástroj pro prijímání těchto opatření považuje tematické strategické dokumenty. Jedná se o dialog Evropské unie či samotných členských států přimo s dotčenými partnerskými zeměmi či regiony. Tento tematický strategický dokument musí být vždy dopIněn právě víceletým orientačním programem, který shrnuje oblasti, které jsou z pohledu Evropské unie považovány za prioritní.

Rozdíl spočivá také v tom, že tematické strategické dokumenty jsou Evropskou komisí schvalovány a víceleté orientační programy jsou komisí prijímány.

\section{Závěr}

Na závěr bych na základě výše zmíněného chtěl podotknout, že toto nařizení má $v$ dnešni době zcela jistě v právním řádu Evropské unie a v její vnější politice smysl. Co by ovšem dle mého zasloužilo revizi či změnu, jsou jednotlivé projekty, které jsou dle mého názoru v nejednom př́padě zcela zbytečně široké a v některých případech, přesto, že ve svém důsledku mohou přispět ke zlepšení určité situace $v$ daném státě, zcela 
jistě nepřinášejí zlepšení, které by bezprostředně přispívalo ke zlepšení bezpečnostní situace. Za zvážení by možná do budoucna stálo $i$ to, že by se Evropská unie více podílela na faktické koncové pomoci, což by zcela jistě vedlo $k$ tomu, že by měla lepší kontrolu nad uvolněnými financemi a mohla tak efektivněji předcházet př́padným zneužitím takto poskytnutých finančních prostředků.

\section{POUŽITÉ PRAMENY}

BERGMANN, Julian. A Bridge over Troubled Water? The Instrument Contributing to Stability and Peace(IcSP) and the Security-Development Nexus in EU External Policy [online]. Bonn: Deutsches Institut für Entwicklungspolitik, 2018, 47 s. [cit. 2019-05-23]. ISBN 978-3-96021-062-7. Dostupné z: https://www.diegdi.de/uploads/media/DP 6.2018.pdf

BERGMANN, Julian. Capacity Building in Support of Security and Development (CBSD): Securitising EU Development Policy? [online]. Bonn: Deutsches Institut für Entwicklungspolitik, 2017, s. 11 [cit. 2019-07-28]. ISBN 978-3-96021-062-7. Dostupné z: https://www.die-gdi.de/ uploads/media/BP_24.2017.pdf.

Evropská komise. Instrument contributing to Stability and Peace manual_of_indicators [online]. Brusel, 2016, s. 16 [cit. 2019-07-28]. Dostupné z: https://www.transtec.be/ website2/pixportal.nsf/pGen00/TRAC-AHVLD6/\$FILE/ manual_of_indicators.pdf

Https://www.international-alert.org/ru/projects/reweaving -ukrainian-social-fabricsocial-fabric 
IÑIGUEZ DE HEREDIA, Marta. Instrument contributing to Stability and Peace - 10 most funded projects in 2018 [online]. [cit. 2019-07-30]. Dostupné z: https://zenodo. org/record/3243973\#.XUCNV44zaW8

MIRANDA, Valérie. Justice cooperation in criminal matters under the EU Instrument contributing to Stability and Peace [online]. Řím, 2014 [cit. 2019-07-30]. Dostupné z: https://www.giustizia.it/resources/cms/documents/italia 2014_ue_roma_miranda.ppt

Nařizení Evropského parlamentu a Rady č. 230/2014. 